\title{
Uterine lavage with saline in mares as treatment for endometritis
}

\author{
R. Mattos, L. F. F. Castiho, E. Malschitzky, A. P. Neves, A. Keller, R. M. Gregory and R. C. Mattos
}

Reprolab, Departamento de Medicina Animal, Faculdade de Veterinária, Universidade Federal do Rio Grande do Sul, Brazil

\begin{abstract}
Summary
Ten mares with ages ranging from 8 to 10 years were experimentally infected with Streptococcus zooepidemicus to determine: 1) if continuous uterine lavages promote the elimination of the bacterial agent, 2) if this elimination occurs before than that caused by the natural defenses of the mare and 3) the number of daily lavages necessary to promote uterine physical clearance. Half of the mares were submitted to 5 lavages per day for 6 days and the remaining were not treated. No significant differences were found $(p>0,05)$ for the elimination of the bacteria between the two groups. An increase in the turbidity of the infused liquid was detected between the $1^{\text {st }}$ and $2^{\text {nd }}$ lavages. Turbidity stabilized between the $2^{\text {nd }}$ and $3^{\text {rd }}$ lavages and decreased from the $4^{\text {th }}$ lavage on. This was observed during the 6 days. It was concluded that uterine lavages in experimentally infected mares promote mechanical cleansing of the uterus, but are not more effective than the natural defense mechanisms of the mare. We recommend the use of at least 4 consecutive lavages for a minimum of 3 days in order to promote an adequate removal of cells and inflammatory by-products from the uterus.
\end{abstract}

keywords: $\quad$ mares, endometritis, uterine lavage

\section{Die Endometritisbehandlung bei der Stute mittels intrauteriner NaCl-Lavage}

Zehn Stuten im Alter von 8 bis 10 Jahren wurden experimentell mit Streptococcus zooepidemicus infiziert. Der Versuchsansatz diente der Klärung von drei Fragen: 1. Wird durch eine kontinuierliche uterine Lavage die Eliminierung der Bakterien begünstigt? 2. Findet die Eliminierung mittels Lavage vor derjenigen durch die natürliche Abwehr statt? 3. Wieviele tägliche Lavagen sind zur Förderung der uterinen Clearance notwendig? Bei der Hälfte der Tiere wurden täglich fünf Spülungen über sechs Tage vorgenommen, die anderen Stuten blieben unbehandelt. Bezüglich der Zeit der Bakterieneliminierung bestanden keine signifikanten Unterschiede zwischen den Gruppen ( $p>0,05)$. Während des sechstägigen Untersuchungszeitraumes wurden folgende Befunde erhoben: eine vermehrte Trübung der Infusionslösung trat zwischen der 1. und 2. Lavage auf. Der Trübungsgrad stabilisierte sich zwischen der 2. und 3. Lavage und sank nach der 4. Spülung. Daraus wird geschlossen, daß eine uterine Lavage bei experimentell infizierten Stuten die mechanische Clearance zwar unterstützt, aber nicht effektiver ist als die natürliche Abwehr der Stute. Wir empfehlen mindestens vier aufeinanderfolgende Spülungen an mindestens drei Tagen, um die Eliminierung von Zellen und Entzündungsprodukten aus dem Uterus zu unterstützen.

Schlüsselwörter: Stute, Endometritis, uterine Lavage

\section{Introduction}

Bacterial infections of the genital tract are an important cause of infertility in the mare (Hughes \& Loy, 1975).

The determinant factor in the mare's reproductive efficiency is its ability in maintaining an uterine environment compatible with embryo and fetal survival. This environment is easily disturbed by the inflammatory process following bacterial invasion (Asbury \& Lyle, 1993), which occurs basically in three situations: natural breeding, gynecological procedures and parturition (Ricketts \& Mackintosh, 1987). Among bacterial agents isolated, Streptococcus zooepidemicus is most frequently seen (Millar \& Francis, 1974; Ferreiro et al., 1986). Allen (1992) considered this bacteria as an opportunist that, reaching the endometrium, can cause inflammation.

After endometrial contamination the uterus begins a response to invasion. Most mares eliminate the agent (Evans et al., 1986) in a few hours or days (Watson, 1988). The best known uterine defenses against bacteria are phagocytosis by neutrophils (Hughes \& Loy, 1969) and mechanical clearance of the uterine lumen (Evans et al., 1986). The combination of efficient phagocytosis and quick elimination of debris brings the uterine environment back to normality (Hughes \& Loy, 1969).

The response to bacterial contamination differs between mares susceptible and resistant to endometritis. Resistant mares are able to control contamination by their efficient defense mechanisms (Asbury \& Lyle, 1993). Susceptible mares, however, cannot eliminate contaminants rapidly enough to assure the embryo an environment compatible with survival.

Susceptibility to uterine infections is related to age and parity (Asbury \& Lyle, 1993). Older mares have an impaired 
uterine clearance ability (Evans et al., 1986) and an increased fluid collection after experimental infection (LeBlanc et al., 1989). After inoculation of $1 \times 10^{6}$ bacteria (S. zooepidemicus) during estrus, myometrial activity of susceptible mares is similar to that of resistant mares during $6-8$ hours, when susceptible mares' myometrial activity declines (Troedsson, 1991).

Uterine lavage has become a popular treatment to endometritis in the last decade (Neely, 1982), being used to promote mechanical clearance of the endometrium. It may also be considered as a pre-treatment, since it facilitates the action of drugs infused later, like antibiotics, which do not act so well in the presence of pus and necrotic tissues (Silva, 1989).

Recent studies on uterine defense mechanisms showed that, besides promoting physical clearance, uterine lavage provokes endometrial stimulation with subsequent rise of neutrophil migration to the uterine lumen (Asbury \& Lyle, 1993).

In addition to enhancing uterine defenses, lavage offers diagnostic advantages in the treatment of endometritis. Inspection of the recovered fluid provides immediate information about the conditions of the uterine lumen. The number of cells and other inflammatory components is correlated to the appearance of the recovered fluid.

Saline $(0,9 \%)$ is currently used for uterine infusion since it produces only mild endometrial irritations (Asbury \& Lyle, 1993). Disinfectant solutions like povidone-iodine can also be used (Silva, 1989), but in vitro studies showed that neutrophils lose their migrating ability when incubated in povidone-iodine solutions more concentrated than $0,2 \%$ (Watson, 1987).

A total volume of one liter can be infused in the uterus without causing discomfort to the mare (Mattos, 1989). As many lavages as necessary are done until reaching adequate uterine cleansing (Silva, 1989).

The objective of this work was to clarify, in mares resistant to endometritis, 1) if continuous uterine lavages eliminate bacteria; 2 ) if this elimination occurs before that provided by the mare's defense mechanisms; 3) the number of lavages needed to promote adequate uterine clearance.

\section{Material and methods}

Ten barren mares with ages ranging from 8 to 10 years were studied. Before the experimental inoculation of the bacteria the mares were submitted to gynecological examination including assessment of perineal conformation, rectal palpation, vaginoscopy, cytological and bacteriological examinations. Only clinically normal mares with negative cytology (absence of PMNs) and no bacterial growth were used.

\section{Experimental infections and treatments}

The mares were inoculated with a $20 \mathrm{ml}$ suspension containing $1 \times 10^{9}$ Streptococcus zooepidemicus $/ \mathrm{ml}$. The bacterial concentration was adjusted with a spectrophotometer. The infusion was performed introducing an insemination pipette through the cervix. The mares were examined twenty-four hours after inoculation and uterine samples for cytological and bacteriological examinations were obtained. If clinical signs of endometritis (flaccid cervix, pathological hyperemia associated or not with the presence of vaginal discharge) and PMN leukocytes in the cytology were detected the mares were assigned to one of the following treatments:

$\mathrm{T} 1$ - Five continuous uterine lavages of $1000 \mathrm{ml}$ saline per day. A Foley modified catheter $n^{\circ} 30$ in closed system was used.

T2 - Control: no treatment.

Each mare was infected four times in intervals of no less than 30 days. After the first infection five mares were treated and five were not. On the $2^{\text {nd }}$ and remainder infections the order of the treatments was inverted, e.g., the mares previously treated became the control group and this group was then treated.

Gynecological, bacteriological and cytological examinations were daily performed in each mare before treatment. Bacteriological examinations ceased when no growth of S. zooepidemicus was detected.

In eight mares experimentally infected and submitted to daily lavages a sample of each infused fluid retrieval was collected in separated tubes in order to evaluate the grade of turbidity. At the end of the daily lavages the five tubes containing fluid samples were submitted to spectrophotometry with a wave length of $545 \mathrm{~nm}$ to determine optical density patterns. A tube with saline was used to adjust the machine pattern.

\section{Statistical analysis}

Analysis of Variance (ANOVA) was used testing the effects of the mares, days, flushings, square effects of flushings and its interactions. When necessary the Bonferroni Test was used to verify differences between means.

\section{Results}

All the mares presented clinical signs of acute endometritis and positive cytology at the first examination performed $24 \mathrm{~h}$ after the experimental infection.

There were no interactions between time to eliminate bacteria among mares.

Table I shows the time needed to eliminate the agent after infection in each treatment.

No significant differences $(p<0,05)$ between the groups concerning to intervals between elimination of bacteria and normalization of clinical findings, as well as between elimination of bacteria and normalization of cytology (absence of PMNs) were observed. Normalization of cytology occurred more frequently $72 \mathrm{~h}$ after elimination of the agent, while clinical signs returned to normal between 48-72 h.

The results of turbidity (optical density pattern) obtained in fluid retrieval of 5 daily lavages during 6 days in 8 mares are shown in Table 2. 
Tab. 1: Mean time needed for elimination of bacteria in each group after onset of clinical signs.

Mittlere Eliminierungszeit der Bakterien nach Auftreten der klinischen Symptome in den Untersuchungsgruppen.

\begin{tabular}{|lccc|}
\hline \multirow{2}{*}{ Treatment } & \multicolumn{3}{c|}{ Time (days) } \\
& $\mathbf{n}$ & $\mathbf{1}$ & $\mathbf{s}$ \\
\hline T1 Lavage & 4,6 & \pm & 0,5 \\
T2 Control & 5,2 & \pm & 0,8 \\
\hline
\end{tabular}

A significant $(p<0,001)$ rise of turbidity between $1^{\text {st }}$ and $2^{\text {nd }}$ lavages can be seen in Table 2. Turbidity stabilized between $2^{\text {nd }}$ and $3^{\text {rd }}$ lavages, decreasing after the $4^{\text {th }}$ one. There were no significant differences between $4^{\text {th }}$ and $5^{\text {th }}$ lavages from the $2^{\text {nd }}$ day on.

The rise of turbidity seen until the $2^{\text {nd }}$ lavage, decreasing after the $3^{\text {rd }}$, was maintained during the 6 days of treatment. However, turbidity attenuated along the days in all lavages. From the $3^{\text {rd }}$ day on, turbidity of the $5^{\text {th }}$ lavage and of the $1^{\text {st }}$ on the following day were similar.

There were no differences between mares and interactions between the different mares and days of treatment.

\section{Discussion}

According to Evans et al. (1986) and Watson (1988), most mares seem to be able in eliminating bacteria by their own defense mechanisms after endometrial contamination. This was confirmed by the control group (T2), in which no treatment was used. In a mean period of 5.2 days after inoculation no bacterial growth could be detected in those mares. The time required to eliminate bacteria was not different between the control group (T2) and the treatment group (T1), what disagrees with findings of Troedsson et al. (1995). The effect of uterine lavage promoting physical cleansing of the endometrium (Silva, 1989) was easily confirmed by visual inspection of the liquid retrieved through the catheter, as well as by the refraction indexes obtained by spectrophotometry. Turbidity rose until the $2^{\text {nd }}$ lavage, what indicates that one lavage is not enough to remove most cells and inflammatory components. This occurred at a greater level on the $2^{\text {nd }}$ and $3^{\text {rd }}$ lavages and subsequently decreased. Physical clearance associated with the stimulus to neutrophils and plasma proteins (Asbury \& Lyle, 1993) was not more effective than natural defense mechanisms on the elimination of bacteria.

\section{$\square$ \\ Unsere \\ Leistungen \\ für Sie:}

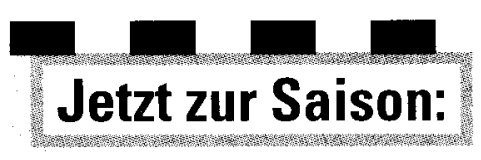

Faire Preise

Tierärztliche

Betreuung

Breite Palette

an Unter-

suchungen

Schnelle

Befund-

übermittlung

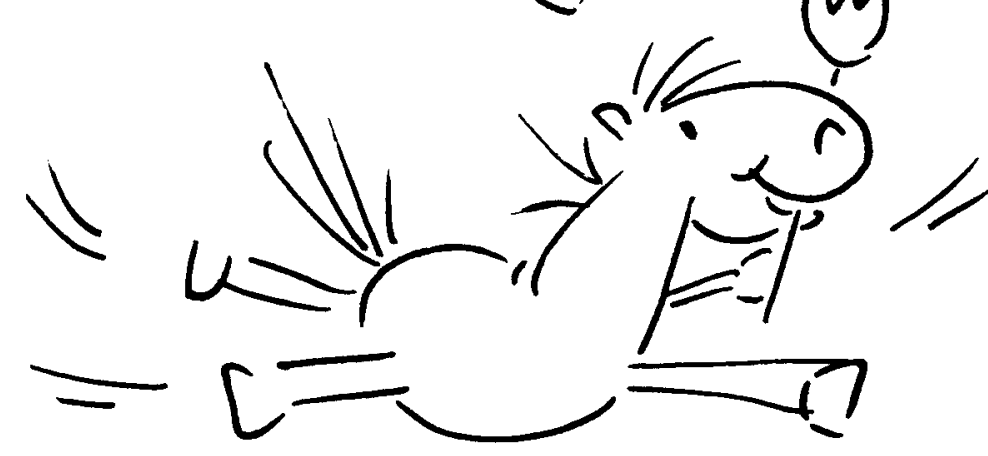

(0)

$\curvearrowleft$<smiles>[CH]1CCCCC1</smiles>
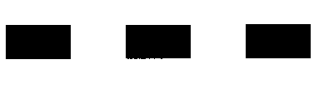

(

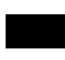

$\square$

5

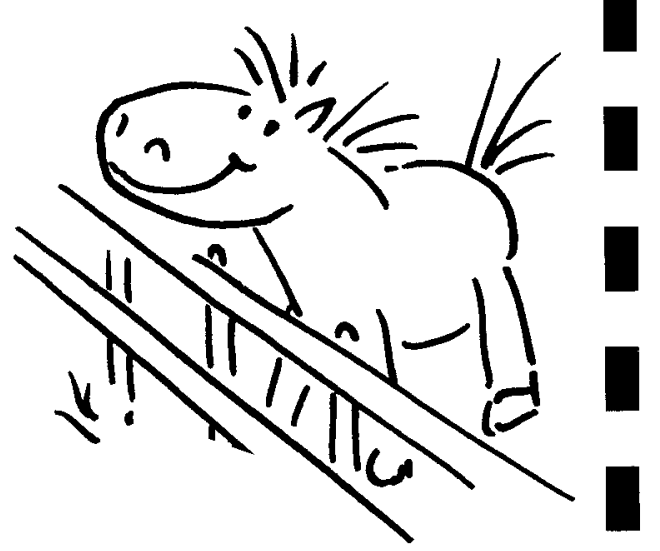

Stutentupfer

Bakteriologische +
mykologische Untersuchung Sonderpreis! $?$ DM

DAS LABOR FÜR TIERÄRZTE

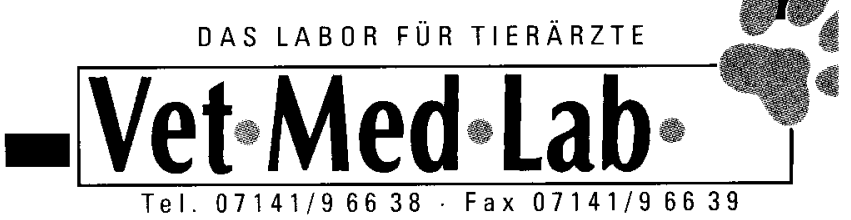


In spite of promoting physical drainage, uterine lavage might not be used as an isolated treatment but as a pretreatment, confirming the statements of Siva (1989). An infusion of antibiotics (Neely, 1982), plasma, or plasma enriched with neutrophils (Castilho et al., 1994) would be indicated after the lavage in order to accelerate the cure.

Tab. 2: Optical density patterns detected in retrieval fluid samples after 5 continuous lavages with saline during 6 days in 10 mares experimentally infected.

Spektrophotometrisch ermittelte optische Dichte der rückgewonnenen Flüssigkeit nach fünf aufeinanderfolgenden $\mathrm{NaCl}$-Spülungen während 6 Tagen bei experimentell infizierten Stuten.

\begin{tabular}{|l|l|l|l|l|l|}
\hline $\begin{array}{l}\text { Lavage } \\
\text { Day }\end{array}$ & $\mathbf{1}^{\text {st }}$ & $2^{\text {nd }}$ & $3^{\text {rd }}$ & $\mathbf{4}^{\text {th }}$ & $\mathbf{5}^{\text {th }}$ \\
\hline 1 & 0.75 & 1.02 & 1.02 & 0.67 & 0.55 \\
\hline 2 & 0.67 & 0.88 & 0.91 & 0.60 & 0.51 \\
\hline 3 & 0.57 & 0.76 & 0.78 & 0.49 & 0.46 \\
\hline 4 & 0.47 & 0.65 & 0.68 & 0.43 & 0.38 \\
\hline 5 & 0.36 & 0.57 & 0.58 & 0.35 & 0.31 \\
\hline 6 & 0.30 & 0.50 & 0.52 & 0.34 & 0.26 \\
\hline
\end{tabular}

The use of sequential lavages is helpful in removing cells and inflammatory components. At least four consecutive uterine lavages were needed to promote an adequate uterine drainage. Most material was removed by lavages in the first 3 days of treatment. Turbidity indexes between lavages showed little differences from the $4^{\text {th }}$ day on, what could be explained by the elimination of bacteria and their consequent decline of the secretions.

It can be concluded that uterine lavages in experimentally infected mares promote mechanical drainage of the uterus, but they are not more efficient than natural uterine defenses. A minimum of 4 consecutive lavages during at least 3 days is indicated to achieve removal of cells and inflammatory components.

\section{References}

Allen, W.E. (1992): Aspects of genital infection and swabing techniques in the mare. Vet. Rec. 104, 228-231.

Asbury, A. C. and Lyle, S. K. (1993): Infections causes of infertility. In: Equine Reproduction. Ed. Mc Kinnon, A., Voss, J. L. Lea \& Febiger, Philadelphia, 381-391.

Castiho, L.F.F. (1994): Endometrite na égua: plasma homólogo acrescido de leucócitos como forma de tratamento. Dissertation, Faculdade de Veterinária da Universidade Federal do Rio Grande do Sul, Porto Alegre, Brazil.
Evans, M.J., Hamer, J.M., Ganson, L.M., Graham, C. S., Asbury, A.C. and Irvine, C. G.H. (1986): Clearance of bacteria and nonantigenic markers following intra-uterine inoculation into maiden mares: effect of steroid hormone environment. Theriogenology 26 , 37-50.

Ferreiro, L., Ferreiro, C., Mattos, R. C., Flores, W., Pansard, H. and Olveira, M.S. (1986): Flora microbiana do conteúdo de éguas P.S.I. e Quarto de Mitha a partir de swabs cervicais obtidos no período 1984-1986 em haras do RS, PR e SP. Arq. Fac. Vet. UFRGS 14, 45-56.

Hughes, J.P. and Loy, R. G. (1969): Investigation on the effect of intrauterine inoculation of Streptococcus zooepidemicus in the mare. Proc. Am. Assoc. Equine Pract., 289-292.

Hughes, J.P. and Loy, R. G. (1975): The relation of infection to fertility in the mare and stallion. Equine Vet. J. 7, 155-159.

LeBlanc M. M., Asbury, A. C. and Lyle, S. K. (1989): Uterine clearance mechanisms during the early postovulatory period in mares. Am. J. Vet. Res. 50 (6), 864-867.

Mattos, R. C. (1989): Manejo Reprodutivo da Égua. In: Sangue e Raça. Ed. Taranto, J.R. Index, Rio de Janeiro, 69-80.

Millar, R. and Francis, J. (1974): The relation of clinical and bacteriological findings to fertility in Thoroughbred mares. Aust. Vet. J. 50, 351-355.

Neely, D.P. (1982): Evaluation and therapy of genital disease in the mare. In: Equine Reproduction. Ed. Neely, D. P., Liu, I. K. M., Hilmann, R. B., Hoffmann-La Roche, New Jersey, 40-56.

Ricketts, S.,W. and Mackintosh, M.E. (1987): Role of anaerobic bacteria in equine endometritis. J. Reprod. Fert. Suppl. 35, 343-351.

Silva, C. A. M. (1989): Infecções Uterinas na égua. Proceedings Congresso Brasileiro de Reprodução Animal, Belo Horizonte, 43-53.

Troedsson, M.H.T. (1991): Uterine defense mechanisms in the mare. Dissertation University of California, Davis.

Troedsson, M. H. T., Scott, M. A., Liu and I. K. M. (1995): Comparative treatment of mares susceptible to chronic uterine infection. Am. J. Vet. Res. 56 (4), 468-472.

Watson, E. D. (1987): Effect of Povidine-iodine on in vitro locomotion of equine neutrophils. Equine Vet. J. 19, 226-228.

Watson, E. D. (1988): Uterine defense mechanisms in mares resistant and susceptible to persistent endometritis: a review. Equine Vet. J. $20(6), 397-400$

\section{R.C. Mattos}

Reprolab, Departamento de Medicina Animal

Faculdade de Veterinária

Universidade Federal do Rio Grande do Sul

P.O. Box 15094, 91501-970 Porto Alegre, Brazil

Tel: $0055-51-3166124$

Fax: 0055-51-3360512

email: mattosrc@vortex.ufrgs.br 